\title{
Appraisal of harmful traditional practices in Nigeria: magnitude, justifications and interventions
}

\author{
Timilehin Olayinka Omoniyi
}

Department of Arts \&amp; Social Sciences Education, University of Ibadan, Ibadan timmylayinka@gmail.com

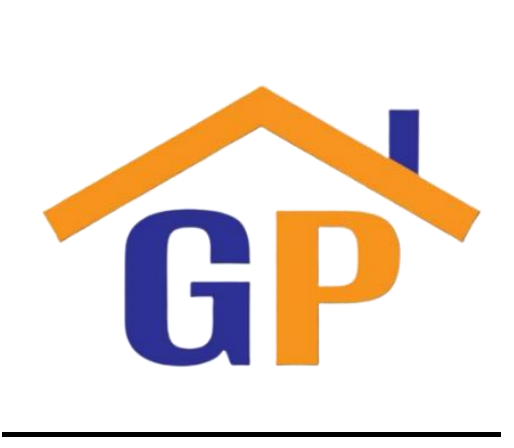

Article History

Received on 14 December 2020

$1^{\text {st }}$ Revision on 4 January 2021

$2^{\text {nd }}$ Revision on 12 January 2021

Accepted on 15 January 2021

\begin{abstract}
Purpose: The study did an appraisal of harmful traditional practices (HTPs) in Nigeria despite global, regional, national laws, policies and programmes, women and girl-children are still being subjected to dehumanising treatments.
\end{abstract}

Research methodology: Systematic search in literature, personal experiences, archival materials, and oral interviews were used in data collection, while thematic analysis was used to interpret oral confessions carried out on thirty-six (36) elderly persons who were purposively selected.

Results: There is high prevalence of HTPs across the Nigeria which the cultural and secular laws are silent about. It was discovered that many children (underage 10-15years of age) in Hausa/Fulani lands are prone to marriage by adoption, force or early marriage of girls between, while in the Eastern part, the is high magnitude of child hustling, outrageous dowry payment, separatist theory as practiced in Osu caste system, servitude (Maid) etc, and in the West are practices of scarification, wife battery, polygamy. They rely on socio-cultural, psycho-sexual, spiritual and aesthetic justifications. The study recommends action-related studies followed by proper education interventions.

Limitations: The study covered HTPs across Nigeria with 36 participants. Further studies should concentrate on tribe or region basis with larger participants.

Contribution: This study did an appraisal of harmful traditional practices in Nigeria; magnitude, justifications and interventions

Keywords: Harmful Traditional Practices, Traditions, Magnitude, Justification

How to cite: Omoniyi, T. O. (2020). Appraisal of harmful traditional practices in Nigeria: magnitude, justifications and interventions. Journal of Social, Humanity, and Education, 1(1), $67-78$.

\section{Introduction}

Traditions are age-long established doctrines, conducts, patterns, and belief systems transferred generation to generation by community members. These are based on cherished societal values which are upheld, guided, protected and enforced by strong prohibitions in bans, fines, taboos and superstitions. Didactic moral lessons are learnt by violators and invariably serve as deterrence for intending offenders (Longman \& Bradley, 2015). Traditions may not be easily changed as it is an established practices and its adherence surpasses generations. Across the globe, countless numbers of people have been subjected to dehumanising practices under the disguise of traditions or culture. Some have been battered, injured, tortured, wrecked and exploited mentally, socially, psychologically, and physiologically due to these age-long practices (UNs, 2006). Nigeria as a multicultural society has rich cultural values and heritage. However, one of the ways prevalent in violating people's 
fundamental human rights, most especially children and women, is through harm traditional practices (HTP).

Harmful Traditional Practices are discriminatory practices committed and accepted by members of a society regularly with sanctions if violated (Jimoh, Adaji, Adelaiye, Olorukooba, Bawa, Ibrahim, Garba, Mfuh, Idris, \& Shittu, 2018). These are beliefs and customs that have harmful effects on the people's lives and wellness and obstruct soundness, goal attainment, livelihood, rights enjoyment, and economic development (Ras-Work, 2006).It has been accepted as parts of way of life without considering its attendant effects. Some sees it as deliberate violence against women and children which considered and presented as acceptable traditional practices. In 2013, six international and inter-regional organisations namely the African Union Commission (AUC), the African Committee of Experts on the Rights and Welfare of the Child (ACERWC), the United Nations Economic Commission for Africa (UNECA), the United Nations Children's Fund (UNICEF/Liaison Office to the AU and UNECA), the United Nations Population Fund (UNFPA/Liaison Office to the AU and UNECA) and the Inter-African Committee on Traditional Practices (IAC) gathered to form a collaborative strategy on how to ameliorate HTPs. According to the body, HTPs are "forms of physical or psychological violence that prejudice the bodily integrity or mental wellbeing of women and children-especially girls- based on the inferior position they have in the social grouping and are considered as long-established and community accepted practices deserving tolerance and respect". The practices are inclusive of all sets of behavior and corresponding attitudes that negatively affect women and children's fundamental rights, such as their right to life, physical integrity, health, dignity, education, and protection from any form of violence (Otinche \& Nnabuenyi, 2015).For instance, child marriage and female genital mutilation are internationally recognised human rights violations. Literature shows that "some 650 million girls and women around the world today have been married as children, and over 200 million have undergone FGM", while it is estimated that, on average, 2 million female children are at risk of Female Genital Mutilation every year at least twenty six percent (26\%) of the fifty three Independent African Countries (UNICEF, 2018; Wadesango, Rembe and Chabaya, 2011).

Globally, there is a high prevalence and generation trends of FGM and early or forced marriage in Malaysia, Indonesia, India, Oman, United Arab Emirate (UAE), Kenya, Djibouti, Sudan, Egypt, Somalia and Uganda suffers and Nigeria in large magnitude (WHO, 2013). For instance, in Nigeria, marriage by adoption, force or early marriage of girls between 10-15years of age, is prominent among the Hausa people in Northern Nigeria, rural communities of Ethiopia and some other developing countries (Onyejiuwa, 2009). Women and children have been at the receiving end of these draconic acts (Walker, 2012) and at greater risks, so also are men exposed to unwarranted practices, though at low rate but capable of taking a toll on their lives. In actual fact in Nigeria and some other African countries, many people or tribes believe in "medicalisation" of harmful traditional practices (Wadesango, Rembe \& Chabaya, 2011)

The table below shows some HTPs in Nigeria with people's justification for engaging in them and where most of these type of acts are carried out.

Table1:Showing Harm Traditional Practices (HTPs) in Nigeria with Justifications

\begin{tabular}{|l|l|l|l|}
\hline S/n & HTPs & People's Justifications (Findings) & Common Among \\
\hline 1 & Early and Forced Marriage & $\begin{array}{l}\text { Tradition demands; Poverty escape; Life value for girl- } \\
\text { child; }\end{array}$ & Hausas/Fulanis \\
\hline 2 & $\begin{array}{l}\text { Female Genital Mutilations } \\
\text { (FGM) (Symphysiotomy) }\end{array}$ & $\begin{array}{l}\text { Socio-cultural and psychosexual reasons; } \\
\text { To shun promiscuity and other Sexual orientations }\end{array}$ & Nearly all tribes \\
\hline 3 & Son Preference & $\begin{array}{l}\text { Socio-cultural factors: Protecting the family 'honour' } \\
\text { and Inheritance }\end{array}$ & Nearly all tribes \\
\hline 4 & Outrageous Dowry & $\begin{array}{l}\text { Cultural value; Pride among community members; } \\
\text { Poverty escape; Recouping Money for Training }\end{array}$ & Igbos, Edos \\
\hline 5 & Early Pregnancy & $\begin{array}{l}\text { Avoidance of Time wastage; Protecting family } \\
\text { 'honour'; To reduce divorce rate } \\
\text { Corrections and Deterrence }\end{array}$ & Hausas/ Fulanis \\
\hline 6 & Corporal Punishment & $\begin{array}{l}\text { Socio-cultural and Aesthetic reasons: Identification and } \\
\text { Ancestry }\end{array}$ & Yearly all tribes \\
\hline 7 & Scarification & & \\
\hline
\end{tabular}




\begin{tabular}{|c|c|c|c|}
\hline 8 & Servitude (Maid) & Informal Education and Skill acquisition system & Igbos and Yoruba \\
\hline 9 & Opening Ancient Calabash & For cleansing or self-killing & Yoruba \\
\hline 10 & Osu Caste System & $\begin{array}{l}\text { Spiritual and social-cultural reasons: Accursed groups } \\
\text { that need to be abandoned }\end{array}$ & Igbos \\
\hline 11 & Honour-based Violence/killings & Bravery & Scanty \\
\hline 12 & Marriage by abduction & Tradition demands, Poverty escape & Fulanis \\
\hline 13 & Gender-based Violence & Male Chauvinism /Patriarchal Belief System & Nearly all tribes \\
\hline 14 & Polygamy & Tradition demands; Man by Nature is a polygamist & $\begin{array}{l}\text { Hausa/Fulanis, } \\
\text { Yorubas }\end{array}$ \\
\hline 15 & Bride Burning & To reduce divorce & $\begin{array}{l}\text { Minute section up } \\
\text { North }\end{array}$ \\
\hline 16 & Acid Throwing & To reduce divorce & Scanty in Nigeria \\
\hline 17 & Bride or Groom Flogging & Open Caning Game for Bride & Hausa/Fulani \\
\hline 18 & Exclusion During Menstruation & Lock-up in a room for days & Nearly all tribes \\
\hline 19 & Arranged Marriage & Making best choice for young ones & Nearly all tribes \\
\hline 20 & Child Abuse or Labour & $\begin{array}{l}\text { To teach Independence, Self-survival, Fend for little } \\
\text { siblings }\end{array}$ & $\begin{array}{l}\text { Nearly all tribes. } \\
\text { Prominent in the } \\
\text { North }\end{array}$ \\
\hline 21 & Virginity Test & Controlling unwanted sexual behaviour & \\
\hline 22 & Breast Ironing & To shun promiscuity & Igbos \\
\hline 23 & Non-inheritance for Women & Socio-cultural factors: Protecting Husband Property & Edos, \\
\hline 24 & Male Circumcision & $\begin{array}{l}\text { Psycho-sexual factors (Overactive and Uncontrollable } \\
\text { sex drive) } \\
\text { To shun promiscuity }\end{array}$ & Nearly all tribes \\
\hline 25 & $\begin{array}{l}\text { Widowhood Discrimination: } \\
\text { Head Shave, Un-bath for } 21 \\
\text { Days, Drink Dead Bathwater, } \\
\text { Marry-the-Dead syndrome, } \\
\text { Sleeping by the Dead }\end{array}$ & $\begin{array}{l}\text { Socio-cultural reasons: } \\
\text { Mark of respect for the late husband } \\
\text { Fact-finding Mission on who killed the Dead } \\
\text { Traditional Marriage with Late Partner }\end{array}$ & $\begin{array}{l}\text { Edos, Yorubas (Ikales, } \\
\text { Ilaje, Apoi) } \\
\text { Igbos, }\end{array}$ \\
\hline 26 & Wife Battery & Completed Dowry paid, Egoistic nature of man & Nearly all tribes \\
\hline 27 & $\begin{array}{l}\text { Untrained Traditional Birth } \\
\text { Attendance and healing }\end{array}$ & $\begin{array}{l}\text { Long History of Usage } \\
\text { Cheap and Affordable }\end{array}$ & $\begin{array}{l}\text { Nearly all tribes } \\
\text { (Rural areas) }\end{array}$ \\
\hline 28 & Herb Concoction Consumption & $\begin{array}{l}\text { Long History of Usage } \\
\text { Cheap and Affordable }\end{array}$ & Nearly all tribes \\
\hline 29 & Infant purging & $\begin{array}{l}\text { Spiritual and religious reasons: } \\
\text { Getting rid of impurities swallowed while in the uterus }\end{array}$ & $\begin{array}{l}\text { Nearly all tribes } \\
\text { (Rural areas) }\end{array}$ \\
\hline 30 & Milk Tooth Extraction & Hygienic and aesthetic reasons; Purifications & \\
\hline 31 & Castigating Barren Woman & Family Continuity Factor & Nearly all tribes \\
\hline 32 & Consulting the Dead & Socio-cultural and ancestry attachment & Nearly all tribes \\
\hline 33 & $\begin{array}{l}\text { Uvulectomy in infants (excision } \\
\text { of the uvula) }\end{array}$ & $\begin{array}{l}\text { Hygienic and aesthetic reasons; } \\
\text { Purifications }\end{array}$ & \\
\hline 34 & $\begin{array}{l}\text { Bloodletting through vein } \\
\text { puncture (Induction of } \\
\text { postpartum hemorrhage to clear } \\
\text { the uterus of impure blood) }\end{array}$ & $\begin{array}{l}\text { Hygienic and aesthetic reasons; } \\
\text { Purifications }\end{array}$ & \\
\hline 35 & $\begin{array}{l}\text { Witchcraft Accusation and } \\
\text { Burning }\end{array}$ & Spiritual and religious reasons & Nearly all tribes \\
\hline 36 & $\begin{array}{l}\text { Thief Burning and Spell } \\
\text { Injection }\end{array}$ & Deterrence & Nearly all tribes \\
\hline 37 & $\begin{array}{l}\text { Discrimination against people } \\
\text { with special ability such as } \\
\text { Albinism, disabilities }\end{array}$ & $\begin{array}{l}\text { Strange human } \\
\text { Worthless value }\end{array}$ & Nearly all tribes \\
\hline 38 & Male Chauvinism & Egocentric nature of man as the head of the family & Nearly all tribes \\
\hline
\end{tabular}




\begin{tabular}{|l|l|l|l|}
\hline 39 & Nutrition Violence & Nutrition help for infants growth and development & $\begin{array}{l}\text { Nearly all tribes. } \\
\text { especially, Gwaris, } \\
\text { Yorubas and Hausas }\end{array}$ \\
\hline 40 & Blood vengeance & Family Honour & $\begin{array}{l}\text { Minute section up } \\
\text { North }\end{array}$ \\
\hline 41 & Bride kidnapping & Socio-cultural reasons: Ceremony required & Fulanis \\
\hline 42 & Dowry Violence & Checkmating women excesses & Igbos \\
\hline 43 & Wife Inheritance Traditions & Culture-demands. Matrimonial requirement & Yorubas \\
\hline 44 & Forced pregnancy & Deterrence System & Hausa/Fulanis \\
\hline 45 & Stoning to death & Hygienic, Purifications and Psycho-sexual reasons & Rural communities) \\
\hline 46 & $\begin{array}{l}\text { Male Child Circumcision } \\
\text { (MCC) }\end{array}$ & $\begin{array}{l}\text { To Pay-up family assumed transgression of some } \\
\text { gender social norms; Protecting family reputations }\end{array}$ & Nearly all tribes \\
\hline 47 & $\begin{array}{l}\text { Honour crime } \\
\text { Socio-cultural reasons }\end{array}$ & Nearly all tribes \\
\hline 48 & Nutritional Violence & Aesthetic factors & Igbos \\
\hline 49 & Eyebrow Incision & Spiritual Cleansing or Purging & Nearly all tribes \\
\hline 50 & $\begin{array}{l}\text { Traditional Deliverance: } \\
\text { Salt or hot water bathing, Broom } \\
\text { Beating, Solitary Confinement, } \\
\text { Deprivation of Food, Water and } \\
\text { Freedom }\end{array}$ & & \\
\hline 51 & Occupational Violence & Responsibility building from Age 10 or 12 upward & Igbos, Hausas \\
\hline
\end{tabular}

Source: Fieldwork, 2020

\section{Literature Review}

On her study, Onyejiuwa (2009) assessed the harmful cultural practices affecting rural women's health. The study of used community-based women organisations in Ebonyi State, Nigeria. Among her major findings shows that majority of the respondents (affected women) were educationally disadvantaged. The study also confirmed that early marriage, female genital mutilation, widowhood practices and nutritional taboos existed and practiced in different locations. The respondents' opinions to the questionnaire were similar to those of the discussants during the (FGD) sessions.

Chukwu, Scent, Emeka, Obi and Kalu (2014) examine some violent cultural practices such as widowhood discrimination, female genital mutilation, wife battery, and early girl child marriage perpetrated against Igbo women in the three senatorial districts of Ebonyi state, South-east Nigeria. To achieve the purpose of this study, four hypotheses were formulated to guide the study. The questionnaire was one the instruments used for data collection. The second instrument: focus group discussion (FGD) while three hundred (300) respondents were selected for the study. Chi square $\left(\mathrm{x}^{2}\right)$ was adopted to test the hypotheses at.05 level of significance. The results rejected the null hypotheses, and accepted the alternate hypotheses. The rejection revealed that these cultural practices were inimical to the development of women.

In 2015, Peterside, Duru, and Anene studied harmful traditional practices in a newborn: A case report. It was discovered that $99 \%$ of the nearly four million newborn deaths occur in developing countries with newborn deaths remaining relatively invisible and neglected. Also, in Nigeria, traditional attitudes and practices dominate newborn care and are often hazardous as most births and newborn deaths in developing countries occur outside healthcare facilities, a reduction in neonatal mortality may depend significantly on interventions involving adaptation of traditional care behaviours practiced at home. However, despite the importance of traditional practices in the newborn period, little is known about these practices' impact on newborn health. The study presented a case of an eighteen day old female who was rushed to the hospital with severe wasting, recto-vaginal prolapsed and septic umbilical cord resulting from repeated traditional home care practices by her mother and grandmother. 
Jimoh et al, (2018) carried out a cross-sectional study of traditional practices affecting maternal and newborn health in rural Nigeria. It was discovered that the median age of marriage and pregnancy were 15 and 16 years respectively; Home births were high (90.4\%) while non-skilled birth attendant was $87.4 \%$. The community had a son preference index ratio of $1: 4.1$. Up to $81.5 \%$ of mothers responded that one form of unhygienic traditional procedure or the other was performed on their children. Time to initiation of breast feeding was in hours in the majority (76.3\%) of mothers, with a high rate of use of pre-lacteal feeds (85.2\%). Being an adolescent mother (AOR 0.403, 95\% CI $0.203,0,797$ ) and utilising a skilled provider at birth (AOR $0.245,95 \%$ CI 0.088, 0.683) were associated with less likelihood of having an unhygienic procedure performed on children.

\section{Theoretical Framework Social Norm Theory}

SNT explains that social phenomena result from people's unplanned interactions over a long period of time and have been seen as acceptable. These social interactions come to play naturally. The theory further explained that if norms can thrive and spread from generation to generation, they can also wear out naturally and die off. Harmful Traditional Practices (HTP) came due to societal norms and conventions that members of the society practice to acquire social status and respect. Members of the communities and families find it difficult to deviate for land norms because of the fear of exclusion and "ostracisation". SNT explains that the family decision to continue to uphold these HTPs largely depends on the decisions of others engaging in them. HTPs can usurp one's protective attitude, thereby promoting compliance of such acts even in the $21^{\text {st }}$ century. When these analogies are clearly understood, ameliorating or abandoning HTPs will be easy, then, global best practices will emerge.

\section{Perusing HTPs Among Major Tribes in Nigeria}

The Igbos occupy Southeastern, Nigeria, precisely called Igbo land are known for patriarchal cultural heritage and male chauvinism (Onyejiuwa, 2009). Many of Igbo women refer to their husband as "Oga" (Boss). The culture and traditions have preference for male child and also permits the male dominion. This shows the level or regard accord to male child. Chukwu (2006) remarked that some of these practices are archaic, dangerous, and damaging to women's psyche. This tends to be very bad for illiterate women (victims), they are bound to be overly subservient and subjected to dehumanising treatment. The egoistic nature of some men in the land drives HTPs (Otinche \& Nabuenyi, 2015). For instance, queens, by traditions are meant to mourn their husbands (kings) for seven odd years before they are lowered and one year after interment. Those without palace's royalties (ordinary women) are meant to mourn their husbands for atleast six months followed by a two years in secluded places as part of the funeral and mourning rites (Nwosu, 2008). This also happens in Yoruba land, Southwestern, Nigeria. In both lands, widows are not meant to take their births for twenty one days after which they are taking to the nearby river where all the public hairs will be shaved and body bathed. This practice varies, in some parts of Igbo land, widows and accompanies are to be naked and must not encounter any human being on their way to such river. Ugwu (2003) added that, if family members suspect any foul play in the death of the man, the woman is forced to drink of the death bathwater. In both land, widow are meant to dress in black, a symbol of bereavement through the mourning process. These and many more are what they are meant to do without as part of the funeral rites of their late husbands, without considering their psychological and emotional consequences for them

In Yoruba land, if a man dies and the wife is of good behaviour to members of the family, she is compelled to marry the late husband's male sibling. Sometimes, even the brother will be the one to ask for his elder brother's wife in marriage. This generates a lot of issues and palpable tension at times. This justification for this is not far-fetched as members of family believes that the children of the late man will be properly monitored if the wife remains in-house. This practice is also not peculiar with the Yorubas alone as other tribes, major or minor within and other Nigeria believe in it. In the same vein, in some parts of Igbo land, widows are not allowed to perform the late respect of dust-todust ritual on late husband as such is likely to build needless bound which may likely debar her from another marriage as any man who has canal knowledge of her after she had done the "dust-to-dust" aspect of the funeral rites, may face untold consequences from the powers that be (Omeje, 2001). It is also the same situation in some cases where the woman is alleged to have committed atrocities and 
she is required to perform some cleansing rituals before being allowed to participate in the burial ceremony of her spouse (Jannah, 2017). These also affect the self-esteem and psyche such woman.

In Hausa land, the religion being practiced in the Northern Nigeria gives room for polygamous relationships (Adebola, Ogunkeyede, Obebe, Olaniyan, Fawole, \& Salman, 2016). A man is allowed to marry more than one wife as supported by the Qur'an while women are only allowed to marry one husband at a time. Women are jealous in nature and are highly dependent on men for much of their survival, this invariably hampers women's rights in such families where there are other wives, hence any acts to revolt are easily checked by husband through withdrawal of their rights and privileges. Many of them suffer untoward hardship, deprivation, humiliation and loneliness. Same applies to the children and teenagers who are subjected to street begging, hard menial labours, farm works and lots more regardless of the climatic conditions. These wreak havoc on the physical being and detrimentally deprived them of education and self-worth (UNICEF, 2020). Also, peculiar to the Hausa/Fulanis is forced and early marriage. Young girls are forced, coerced and advised to bring home suitors are early as ages 12 and 15 . As main victims, some of them are kidnapped and if they resist such, it is believed such act will bring unimaginable disrepute to the name of the family. Hence to satisfy the parents' needs and by extension traditional practices, they have no option than to give in. While some may go gaga, employing a radical approach by committing suicide. These unwholesome practices are dehumanising, the UNs and other regional bodies have continued to kick against it in strong terms possible.

\section{Negative Impacts of HTPs}

Victims are subjected to thorough scrutiny, out-of-school punitive measure, self-survival, early motherhood for forced pregnancy, beating, bullying and even death. These implications are nosedived into solitary confinement, suffering, pains, unemployment, economic downturn, and limited financial and career opportunities. There are numerous reasons why HTPs continue to evolve unabatedly. Glover, Liebling, Goodman and Barrett (2018) said that families of victims or the perpetrators are only trying to ensure that morals are upheld, maintaining the forefathers' legacies, protecting family honours, preventing unforeseen circumstance, guiding against violence. These scholars categorised into socio-cultural, psychological, religious, psychosexual, wellness, hygienic and aesthestic reasons, however these factors are not tenable in the face of International and National laws and conventions (UNs, 2017; 2020). Many parents desire to have their girls married to see their grand-children and reduce promiscuity and promote family honour of having their children married as virgins. These acts have significant effects, most especially the health and wellness of children and women. Many are plunged into mental, emotional, psychological pains and deteriorating reproductive health as well as denial of basic fundamental human rights such as education, freedom of choice, movement and association (WHO, 2020). For instance, in this 21 st century, more than $35 \%$ of children are still being delivered by quack midwives, unlicensed and untrained personnel (WHO, 2020). While some of this personnel carry out their illegal jobs, untold pains, bleeding and times lost of lives or parts of the body often occur (NPC, 2013). Many are disfigured, burnt and cut beyond recognition. These practices go against people's fundamental human rights as they have rights and freedom to enjoy other than witnessing pains, suppression, repression, discrimination, and genderbased violence. However, it occurs across all genders, cultures and religions. Thousand and one legislations have been made to ameliorate the evil effects of harmful traditional practices. However, the will to make it useful is lacking as no uncompromising commitments have been made to completely stop these acts across the country's length and breadth.

\section{Global Laws, Policies and Programmes against Harmful Traditional Practices (HTPs)}

Across International laws and conventions are Rights which protect people from harmful traditional practices; Right to life and health; Right to non-discrimination on the basis of sex, Right to liberty and security; Right to freedom from inhumane and degrading treatment. By 2015, Sustainable Development Goal (SDGs) kicked against HTPs by calling for advanced rights for girl-child and women across the globe. Also, UNICEF advocates for child's protection from violence and exploitation of any magnitude, which considers HTPS. This makes UNICEF develop a workable Strategic Plan 2018-2021 for global awareness, orientation, enforcement of national laws, quality prevention, care services, and collection of data for wider analysis as this will help eliminate common 
HTPs affecting children. The collaborative efforts with other United Nations Agencies like UNFPA have reached out to over 5 million adolescent girls in 46 countries. About 7 million volunteers help in the awareness exercise, most especially on Female Genital Mutilation (FGM) (OHCHR, 2020). In Article 24(3) of the Convention on the Rights of Child requires State Parties "take all effective and appropriate measures intending to abolish traditional practices prejudicial to the health of children" .

In Article 21 of the African Charter on the Rights and Welfare of the Child obliges State Parties to:"...take all appropriate measures to eliminate harmful social and cultural practices affecting the welfare, dignity, normal growth and development of the child and in particular:(a) those customs and practices prejudicial to the health or life of the child; and (b) those customs and practices discriminatory to the child on the grounds of sex or other status. Child marriage and the betrothal of girls and boys shall be prohibited and effective action, including legislation, shall be taken to specify the minimum age of marriage to be 18 years and make registration of all marriages in an official registry compulsory." In Article 5 of the Protocol to the African Charter on Human and Peoples' Rights on the Rights of Women in Africa (the Maputo Protocol), adopted in 2003, requires States to "prohibit and condemn all forms of harmful practices which negatively affect the human rights of women and which are contrary to recognised international standards."

According to Otinche and Nnabuenyi (2015), the following are some other International Laws and Conventions which spelt out the rights of every citizens and protection against oppression and other forms of dehumanising acts:

i. The Magna Catha, 1215;

ii. The Petition of Rights, 1682;

iii. The Bill of Rights, 1689;

iv. The Virginia Declaration of Right, 1776;

v. The French Declaration of the Rights of Man and the Citizen, 1789;

vi. The Universal Declaration of Human Right, 1948;

vii. The European Convention for the Protection of Human Rights and Freedom, 1950;

viii. The American Convention for the Protection of Human Rights and Freedom, 1959;

ix. The African Charter on Human and People's Rights, 1986; (Ojo, 2006, p.16);

$x$. The United Nations International Convention on the Elimination of All Forms of Racial Discrimination, 1966;

xi. The United Nations Convention on Economic, Social and Cultural Rights, 1966;

xii. The United Nations Convention on Civil and Political Rights, 1966;

xiii. The United Nations First Optional Protocol to the International Convention on Civil and Political Rights,1966;

xiv. The United Nations Convention on the Elimination of All Forms of Discriminations against Women, 1979;

xv. The United Nations Convention against Torture and Other Cruel, Inhuman or Degrading Treatment or Punishment, 1984;

xvi. The United Nations Convention on the Rights of the Child, 1989;

xvii. The United Nations Optional Protocol to the Convention on the Elimination of All Forms of Discrimination against Women, 1999;

xviii. The United Nations Optional Protocol to the Convention on the Rights of the Child on the Sale of Children, Child Prostitution and Child Pornography, 2000;

xix. The United Nations Optional Protocol to the International Convention on Economic, Social and Cultural Rights, 2008;

\section{Nigeria Laws, Policies and Programmes against Harmful Traditional Practices (HTPs)}

The Constitutions of the Federal Republic of Nigeria of 1960, 1963, 1979 and 1999 as amended in 2011 go against HTPs. These domestic legal framework outline clearly, in the constitution, prohibitions of violence against women and girls, HTPs, FGM. For instance, the Nigeria Constitution stated in Article 15 (2) and 17(2) prohibits discrimination against anybody and in Article 34(1) re-affirmed that every individual is entitled to respect for the dignity of their person and, accordingly, no one 'shall be subject to torture, or to inhuman or degrading treatment". Specifically, at State level, in 1999, Edo kicked against FGM with Prohibition of Female Genital Mutilation Law (1999); in 2000 and 2001 Cross River (The Gird-Child Marriages and Female Circumcision 
(Prohibition) Law) and Ebonyi (Law Abolishing Harmful Traditional Practices Against Women and Children) followed suit. Three years later in 2004, Bayelsa and Enugu made prohibitive laws against FGM. By 2009, Rivers State promulgated the Child Rights Act (2009). It was on $25^{\text {th }}$ May, 2015, that law on Violence Against Persons (VAP) (Prohibition Act) which is the was first federal law attempting to go against FGM. It is also championed gender-based violence in both private and public lives. In Northern region of the country where Sharia laws serve as guide and framework has letters prohibiting HTPs as well as ones protecting women and children from dehumanising, and psychological violent conducts and practices. Some of these states are Zamfara, Sokoto, Kaduna, Kebbi, Ancient city of Kano and other parts.

\section{Research methodology Research Review}

The study adopts a systematic review research design which is appropriate as no attempt is made to manipulate the manifestation of Harmful traditional practices in Nigeria. The research review covers the magnitude, justifications and commonality of HTPs in Nigeria with a view to mitigating the evil effects on the Nigeria people.

\section{Population and Sample}

The population of the study comprises of all citizens of the country. Participants for this study were drawn from the thirty six states of the federation. A total of thirty six (36) elderly persons within the age range of 50 to 70 were purposively selected. The sole criterion for this is that such person must be resident of or lived in their respective states in Nigeria from birth. This is to give nearly all states of the federation equally chances and to be able to elicits vital information for study.

\section{Instrument}

Structured Interview Guide on Harmful Traditional Practices (SIGHTPs) was designed to elicit information from Nigeria's sampled participants. Section A seeks to obtain the respondents' demographic data such as name, profession, state and years of residence, while section B consists of 9 items. In order to ensure both face and content validity of the instrument, it was shown to experts in the field of Social studies, Social works, Psychology, Adult and Language Education for corrections on the suitability of the content and language of presentation. The indepth interview took six (6) months across the country.

\section{Findings of the Reviewer: Thematic Analysis of the Oral Interview}

Magnitude: Participants were interviewed on HTPs and why such as continue unabatedly. A large percentage of the interviewed mentioned that: It has been on for many years and the trend continues. For instance, Participant $\left(\mathrm{P}_{5} \mathrm{~W}_{55}\right)$ opined that "It is everywhere. No country, tribe, group or culture, whether in the developed, developing or under-developed societies that has no measure of HTPs. it only manifest at different levels. Some detrimental, painful, enduring, cautious in nature and appealing, hence we can't conveniently jettison them all. Even men are not excluded from these acts but they are strong to withstand, compliance, rejection of its enforcement measures, fight their way out and other strategies used for abstinence from it." Another participant $\left(\mathrm{P}_{7} \mathrm{M}_{46}\right)$ remarked that "it has raised international concerns and received wide condemnation from all reputable sources and contacts in human rights advocacy and health issues". Furthermore, Participant $\left(\mathrm{P}_{6} \mathrm{M}_{39}\right)$ said; "its manifestations promote gender inequality, absence for human dignity, generational agony, trauma and lots more. it needs to stop". There is no doubt that HTPs have come to stay. It could also be deduced from their responses that there are thousand and one HTPs across religions, regions and ethnic divides in a multicultural, multi-religious and democratic society like Nigeria. It could also be deduced that some of these practices have painful results from generations to generations.

Justification: On the justification for such acts, many participants interviewed opined that it was; to shun promiscuity, protecting husband property, socio-cultural, psycho-sexual (overactive and uncontrollable sex drive), hygienic and aesthetic, spiritual and religious reasons. For instance, some of the participant $\left(\mathrm{P}_{1} \mathrm{~W}_{41}\right)$ opined that; "many of these children are being prepared and taught native intelligence, home training, duty to assist parents in generating income, capacity building and acquisition of local business acumens which have stood a test of time, generations to generations, especially in agriculture". She further said, "though atimes, this affect their formal schooling, innate talents, puts them in danger and unnecessary acquaintances with strangers. They are also exposed 
with street hazards, sexual and physical abuse among others". This is a testament to fact that HTPs are deliberate acts for cultural and personal reasons. Another participants $\left(\mathrm{P}_{2} \mathrm{~W}_{48}\right)$ said; "Uvulectomy in infants (excision of the uvula) is a honest gesture which basically remove foul smell, pus, swelling, disruption to the uvula which could lead infants to death if adequate care is not taken". There is no doubt that HTPs have come to stay, and everyone to is trying to be protective of children from sexual perversion as in cases of FGM; escape from power, where children hawk to support the family, culture and traditions preservation, hygiene in circumcision, and aesthetic (beauty) in case of scarification and identity. It could also be deduced from their responses that Western life's introduction cannot really serve as substitution for the cultural heritage. Many generations have been toeing the path with minimal regrets. Participants $\left(\mathrm{P}_{4} \mathrm{~W}_{62}\right)$ remarked that;"home delivery was what many of us go through while our parents gave birth to us. Today, western world has taken over. However, there is no justification for not adopting a cleaner or safer means to Female Genital Mutilation (FGM), Male Child Circumstance (MCC), and other abuses to women and children. 'The preference for engaging in HTPs is rooted in cultures and values of the land and not of the country formed by human, even the laws are against it.

Interventions: Participants were asked how such HTPs could be ameliorated. Many of their responses include; seminars on better or modern ways to go about it, symposia, and penalties for crude violators. Participants interviewed on HTPs stated that: school teachings, media programmes, religions perspectives should be used to educate the masses. There is no doubt that the effects of HTPs on people's health and wellness can be solved if proper policies and programmes are put in place to check excesses. It could also be deduced from their responses that many of them are "sick and tired" of the dastardly acts and want a proper way to stop several, which have detrimental effects on human lives and dignity.

\section{Implications for Individuals' life, Societal Growth and Development}

Indeed, Nigeria is culturally endowed but HTPs are obsoletes, destructive and dangerous and are still been passed across generations, even in this present civilised global world. HTPs are violent cultural encumbrances that are condemnable by every standard and measures whether under international and local laws. For instance, group scarification is capable of promoting community transmission of communicable diseases like HIV/AIDS, STIs, Corona Virus Pandemic (Covid_19) and lots more with repercussive effects. Hence, human dignity of splendor, honour and respects should be accorded to all and sundry. The prerogative and quality of human being, both man and woman, young and old is fundamentally significant and unquestionably equal as people should be allowed to pursue their interest, yearning and aspirations in a civil manner irrespective of social standing, belief system and doctrines, more importantly under human rights laws.

\section{Physical, Health and Wellness Implications}

i. Psychological and mental illness, diseases and infirmities

ii. Disable citizens, especially in women and girl-children

iii. High mortality rates

\section{Social Implications}

i. Low self extreme

ii. High rate of suicide due to mental breakdown

iii. Absence of peace of mind and societal tranquility

iv. Bruised and battered persons are bound to be destructive in the society

v. Broken relationship likely to produce rascals and social miscreants in the society

\section{Economic Implications}

i. Increase in poverty rate as many victims (young girls, women) may not be productive again

ii. Absence of Small and median scale enterprises (SMSEs)

iii. Persistent inflation in prices of commodities

\section{Political Implication}

i. Low involvement in politics due to patriarchal design of the society which favours men

ii. Poor civic engagement due to male chauvinism

\section{Legal Implications}

i. Weak and non-implementable laws, policies and programmes against HTPs will continue to dent the image of the judiciary and country at large 
ii. Expenses as result of legal tussles of between perpetrator and victims

\section{Conclusion}

HTPs are pandemic in nature and widely varied. They are rooted in discrimination based on gender, age, status and conditions. It has been found to rely on socio-cultural, psycho-sexual, spiritual factors, societal customs, values and misconceptions, and is usually against women and children. The nature, magnitude varies across tribes and tongues with destructive effects. The most prevalent of HTPs in Nigeria is child labour, early marriage, female genital mutilation (FGM), male child circumcision (MCC), polygamy and other crimes associated with dehumanising conditions in the name of abject poverty, cultural requirement, family honour and age-long traditional patterns. As solid as these laws maybe on paper, the effectiveness in implementing it is usually very weak. Many countries of the world do not always believe in honouring international laws and conventions they signed to. Only morally conscious nations with strong commitment to the Rights of her citizens tend to abide by the provisions of the laws. There continued to be false belief and weak justifications across ages, and even to this current dispensation. It is not easy to change age-long belief system except through continuous orientations, educations, societal support, traditional and religious leaders' advocacy and the media's programmes and policies.

\section{Recommendations}

HTPs and its attendant consequences are preventable hence,

1.There is need for more global and national awareness, moral out-door education, campaigns, and sensitisation to all rural communities where many of these dastardly acts are being perpetrated. This will emphasise the negative consequences of HTPs on society members as showcase the Human Fundamental Rights against these dehumanising treatments.

2. Government needs to be proactive in amelioration evil effects of HTPs on lives and livelihood of the Nigeria people.

3. There is need for special focus of actions towards main drivers of HTPs, who are mostly men who serves as leaders and elders in the society, by re-directing them to uphold and engage in harmless traditional practices. Most significantly, traditional institutions should be saddled with the responsibility of re-orientating their subjects on global best practices of treating human beings

4. There is need for action-related studies followed by proper education intervention through video, pictorial and prints evidence to portray the effects of harmful traditional practices to be shown or pasted on every nook and cranny of the society. This will tell the horror story people go through daily as a result of HTPs

5. Also, adequate infrastructural facilities, resources and technical support should be provided mostly in rural community where such practices are high.

6. Finally, community-based approach could also be employed through creating a pool of like-minds, door-to-door talk, watchdog role, whistle-blowing methods, peer-to-peer discussion forum, sports and games with inscription negating HTPs etc.

7.Policies and programmes to empower women and children who are victims of the dehumanising acts

8. There is need to re-activate "sleeping or dead laws" on the fight against HTPs

9.Wings of the Nigeria law enforcement agencies should be empowered to arrest and prosecute offenders with stringent penalties like jail terms, fines and even excommunication gestures are meted out.

Competing Interests: The authors declare no competing interests

Funding: None

\section{Acknowledgement}

I sincerely thank everyone who came up with constructive criticism and technical expertise which helped to advance this study. The argument presented here as per harmful traditional practices is based on literature, personal experiences, archival materials, and oral interviews. This has given the work a national outlook as well as shapens my intellectual disposition. I extend my deepest 
appreciation to interviewed participants, those who facilitate the archival materials accessed and other logistics put in place to produce this paper. I thank you all.

\section{References}

Adebola S.O., Ogunkeyede S.A., Obebe F.A., Olaniyan O.D., Fawole O.B., \& Salman A. (2016). Profile of pediatric traditional uvulectomy in North-West Nigeria: the need for caution and education. IntJPediatrOtorhinolaryngol, 88, 194-8.

Chukwu C.C. (2006) Socio-cultural practices as obstacles to women empowerment in $\quad$ Nigeria: $A$ case of Bekwarra, Ogoja and Yala local government Areas of Cross River State. Unpublished M. Sc thesis submitted, University of Calabar, Nigeria.

Chukwu, C. C., Scent, G.A.T, Emeka, J., Obi, C.U. \& Kalu, E,O. (2014) Violence against women in Igbo land, South-east, Nigeria: A critical quest for change ol. 6(2), 49-58.

FGN. (2001). Nigeria Constitution Article 15 (2) and 17(2) (Working Document) Abuja

Glover, J., Liebling, H., Goodman, S., \& Barrett, H. (2018). Persistence and resistance of harmful traditional practices (htps) perpetuated against girls in Africa and Asia. Journal of International Women's Studies, 19(2), 44-64. Available at: https://vc.bridgew.edu/jiws/vol19/iss2/4 Https://www.28toomany.org/nigeria/.accessed 17th Nov. 2020

Jannah, I. (May 25, 2017). Widows: some harmful practices they experience in Igbo land. Accessed on 2nd December, 2020

Jimoh et al. (2018). A cross-sectional study of traditional practices affecting maternal and new-born health in Rural Nigeria Pan Afr Med J. 31 (64)

Longman C. \& Bradley T. (eds.) (2015). Interrogating harmful cultural practices: $\quad$ gender, culture and coercion, routledge, pp. 51-66

National Population Commission (NPC) [Nigeria] and ICF International. (2014). Nigeria demographic and health survey 2013. Available at http://dhsprogram.com/pubs/pdf/FR293/FR293.pdf

Nwosu C.J. (2008) 'The girl child, still run your race' in nigeria and the millennium development goals, Lagos: Fulbright Alumni

OHCHR, Fact Sheet No.23, Harmful traditional practices affecting the health of women and children. http://www.ohchr.org/documents/publications/factsheet23en.pdf, accessed 2nd December, 2020.

OHCHR, UNFPA, UNICEF, UN Women and WHO, Preventing gender-biased sex selection: an interagency statement. 2011 Accessed on 2nd December, 2020

Omeje, K. (2001). 'Sexual exploitation of cult women: the challenges of problematising harmful traditional practices in Africa from a doctrinalist approach', social and legal studies, 10(1), 45-60.

Onyejiuwa, M.F. (2009). An assessment of the harmful cultural practices affecting the health of rural women: a study of community based women organisations in Ebonyi state (Phd Thesis, department of adult education and extra-mural studies; university of nigeria, nsukka)

Otinche S.I. \& Nnabuenyi, U.M. (2015). Culture and the right of the rural woman in Nigeria: an overview. International Journal of Basic, Applied and Innovative Research IJBAIR, 2015, 4(2):30-43. Retrieved on 2nd December, 2020 from www.arpjournals.com;

www.antrescentpub.com

Peterside O, Duru C.O., \& Anene N. (2015). Harmful traditional practices in a newborn: A case report Niger J Paed 2015; 42 (2):151-153

Ras-Work B. (2006) 'The impact of harmful traditional practices on the girl child', UNICEF Innocenti Research Centre, Florence, Italy

Report of the Secretary-General on ending female genital mutilation, E/CN.6/2012/8, 2011 Accessed on 2nd December, 2020. The International NGO council on violence against children, violating children's rights: harmful practices based on tradition, culture or superstition, 2012

Ugwu N.S. (2003). The agony of a woman jos: Verdem Publishers. 
UN Study on Violence Against Children. (2006). Accessible at: http://www.unicef.org/violencestudy/

UNFPA. (2005). Child marriage factsheet accessed on 2nd December, 2020

UNICEF Child Info, Child Marriage: Progress. January 2012. http://www.childinfo.org/marriage_progress.html accessed 2nd December, 2020

UNICEF. (2020). Early Marriage: A harmful traditional practice. 2005 accessed on 2nd December, UNESCO Publishing.

Union, A. (2003). Protocol to the African Charter on Human and People's Rights on the Rights of Women in Africa. Maputo: African Union.

Wadesango N, Rembe S \& Chabaya O. (2011). Violation of women's rights by harmful traditional practices. The Anthropologist; 13(2): p121-129

Walker J.A. (2012). Early marriage in Africa--trends, harmful effects and interventions. Afr $J$ Reprod Health, 16 (2), 231-40

WHO, Fact Sheet. (2013, December, 2). Female genital mutilation, retrieved from http://www.who.int/mediacentre/factsheets/fs241/en/ accessed February 2013

Wikipedia. (2020). African charter on the rights and welfare of the child retrieved From: $\mathrm{Http} / /$ En.Wikipedia.Org/African-Charter-on-the-Rights-and-Welfare-of-the-Child (Accessed 5th November, 2020)

Wikipedia. (2020). Convention on the Rights of child, Retrieved From: Http//En.Wikipedia.Org/Convention-on-the-Rights-of-Child (Accessed $5^{\text {th }}$ November, 2020) 